УДК 343.59:725.94

DOI https://doi.org/10.32837/yuv.v0i4.1994

К. Гуляков,

аспірант кафедри галузевого права

Херсонського державного університету

\title{
ЕВОЛЮЦІЯ ЗАКОНОДАВСТВА ПРО ОХОРОНУ ОБ'ЄКТІВ ІСТОРИЧНОЇ ТА КУЛЬТУРНОЇ СПАДЩИНИ ПРОТЯГОМ ХХ СТОЛІТТЯ
}

Постановка проблеми. Після захоплення влади більшовиками на українських землях відбулася руйнація системи вітчизняного кримінального права 3 його концептуальними основами на базі класичної школи права, що супроводжувалося деюридизацією основних інститутів кримінального права, насамперед злочину (відмова від ознаки протиправності), теоретично обгрунтованих соціологічною школою кримінального права. Відмова від ознаки протиправності відкривала шлях до необгрунтованих репресій, до масового знищення людей, пошкодження та наруги над пам'ятками історії і культури.

Така політика була підтверджена одним із перших декретів Радянської влади - декретом «Про знесення пам'ятників, споруджених на честь царів та їніх слуг, і створення проектів пам'ятників Російської соціалістичної революції» від 14 квітня 1918 року, хоча при цьому перед владою постала гостра необхідність вживання заходів, спрямованих на врегулювання проблеми розкрадання, масового вивезення за кордон й інших посягань на культурні та історичні цінності.

Аналіз останніх досліджень i публікацій. Різні аспекти проблеми кримінально-правової охорони об'єктів історичної та культурної спадщини досліджувались вітчизняними фахівцями, такими як B.I. Акуленко, Р.В. Асейкін, В.В. Базелюк, С.О. Бочарников, К.І. Бусол,
Є.П. Гайворонський, В.Ю. Докучаєва, Т.Г. Каткова, В.В. Кузнецов, H.I. Кудерська, Є.I. Кузьменко, Т.В. Курило, В.А. Ломако, П.С. Матишевський, О.I. Мельничук, М.О. Міщенко, В.О. Навроцький, Б.М. Одайник, І.Г. Поплавський, I.В. Пивовар, С.С. Птуха, О.С. Сотула, О.В. Усенко, М.І. Хавронюк та іншими, але в сучасних умовах побудови правової держави ця проблематика набуває особливого значення, тому іï наукова розробка не втрачає своєї актуальності.

Метою статті $€$ розкриття проблеми формування інституту кримінально-правового захисту об'єктів історичної та культурної спадщини з урахуванням сучасних досягнень кримінально-правової науки.

Виклад основного матеріалу. 23 серпня 1922 року було прийнято перший Кримінальний кодекс УРСР (далі - КК УРСР), який копіював відповідний Кримінальний кодекс РСФСР 1922 року і передбачав норми, що встановлюють відповідальність за посягання на культурні цінності. Визначалась злочинною контрабанда (кваліфікований вид - незаконне вивезення або ввезення історичної і культурної спадщини) (ч. 2 ст. 97 KK УРСР 1922 року) [1, с. 35], встановлювалася кримінальна відповідальність за наругу над пам'ятником революції (ст. 87 КК УРСР 1922 року) [1, с. 33] та за приховування колекцій пам'ятників старовини і мистецтва, що підлягають реєстрації і обліку або пере- 
дачі в державне сховище (ст. 102 KK УРСР 1922 року) [1, с. 36]. Кримінальний кодекс УРСР 1922 року, як і більшість інших правових актів, характеризувався слабкою правовою охороною культурних цінностей. Існуючі законодавчі акти носили класовий характер і метою своєю мали вирішення політичних питань. Власниками предметів, що мали культурну або історичну цінність, були зазвичай представники інтелігенції, буржуазії та інших імущих класів, таким чином, суб'єктами вказаних злочинів, як правило, були представники перерахованих вище класів. Крім того, пробілом кримінального законодавства УРСР була відсутність закріплення інших видів посягань на культурні цінності, а саме: розкрадання, знищення або пошкодження тощо. Більша частина вже наявних і нововиданих правових документів, що регулювала відносини у сфері культурної спадщини, виявилася малоефективною і найчастіше носила декларативний характер [2, с. 30].

8 червня 1927 року був прийнятий новий Кримінальний кодекс УРСР [3]. Аналіз показав, що у KK УРСР 1927 року містилася лише одна норма, що охороняла пам'ятники історії і культури від злочинних посягань. Встановлювалася відповідальність за приховування колекцій і пам'ятників старовини і мистецтва, що підлягають реєстрації, обліку або передачі в державні сховища. За це суспільно небезпечне діяння передбачалося покарання у виді виправних робіт на строк до трьох місяців 3 конфіскацією приховуваного майна [3, с. 63]. Інші посягання на культурні цінності передбачали кримінальну відповідальність у загальному порядку, тобто поза увагою залишилися діяння, пов'язані з викраденням, знищенням та пошкодженням культурних цінностей та незаконне проведення робіт на об’єкті археологічної спадщини.

Однак при цьому дослідник історії охорони культурної спадщини
Н.I. Кудерська зазначає, що, використовуючи гасла боротьби з релігією та планами перебудови і реконструкціï населених пунктів, приймалися рішення про руйнування культурних надбань [4, с. 22].

Істотних втрат зазнала культурна спадщина України під час Другої світової війни. За неповними даними, було зруйновано біля однієї тисячі цінних пам'яток архітектури, з яких 347 втрачені повністю [5, с. 706].

Протягом 1944-47 років в Україні було відновлено державну систему органів охорони пам'яток на центральному та обласному рівнях, яка включала в себе Урядову комісію з охорони пам'яток культури і старовини, Управління охорони пам'яток культури і старовини при Комітеті у справах культурно-просвітніх установ (історія, археологія, мистецтво), відділ охорони пам'яток при Управлінні у справах архітектури [5, с. 706].

$\mathrm{y}$ шістдесятих роках минулого століття зміна суспільно-політичної обстановки в СРСР, зосередженість суспільства на відновленні економіки держави та певна гуманізація призвели до значного зменшення злочинності проти історичної та культурної спадщини, що зумовило зниження уваги до проблем кримінально-правової охорони культурних та історичних цінностей.

Така ситуація спостерігалася до моменту прийняття у 1958 році Верховною Радою СРСР Основ кримінального законодавства Союзу СРСР і союзних республік, які стали основою для створення та прийняття 28 грудня 1960 року нового КК УРСР, який набрав чинності 31 квітня 1961 poky [6].

У КК УРСР 1960 року відбулася декриміналізація діяння, яке полягало в приховуванні колекцій і пам'ятників старовини і мистецтва, що підлягають реєстрації, обліку або передачі в державні сховища, і була запроваджена принципово нова норма про знищення i зруйнування пам'яток культури, 
передбачена статтею 207 KК УРСР 1960 року. На думку вітчизняних учених, дослідників кримінально-правової охорони культурної спадщини, незважаючи на деяку однобокість у правотворчості, (полягала в тім, що серед кримінально-правових засобів, які забезпечували використання і схоронність культурної спадщини, були закріплені тільки засоби боротьби з неналежним поводженням 3 ними), дана кримінально-правова норма мала i свій позитивний вплив на розвиток законодавства в досліджуваній області. Більше чітке визначення одержав предмет злочинного посягання, сформульований як «пам'ятники історії і культури» [2, с. 31].

Стаття 207 KK УРСР 1960 року передбачала відповідальність за умисне знищення, зруйнування чи зіпсування пам'яток культури або природних об'єктів, взятих під охорону держави. У коментарях до цієї статті зазначалося, що «охорона пам'яток культури та природних багатств є важливим завданням нашої держави і всієї радянської громадськості. 3 огляду на особливу цінність пам'яток культури в природних об'єктів, узятих під охорону держави, коментована стаття встановлює кримінальну відповідальність за умисне ïх знищення, руйнування і псування» [7, с. 543].

Як зрозуміло 3 диспозиції статті 207 KК УРСР 1960 року, предметом даного злочину були пам'ятки культури або природні об'єкти, взяті під охорону держави.

Суттєві зміни в характеристику об'єктів історичної та культурної спадщини було внесено прийнятим Верховною Радою УРСР 13 липня 1978 року Законом Української РСР «Про охорону і використання пам'яток історії та культури» [8], за яким пам'ятки історії та культури поділялися за видами на пам'ятки історії, археології, містобудування і архітектури, мистецтва та документальні пам'ятки; визначався порядок орга- нізації державного обліку пам'яток; державне управління пам'яткоохоронною галуззю покладалося на Раду Міністрів УРСР, а спеціально уповноваженими державними органами охорони пам'яток історії та культури, як і раніше, залишалися Міністерство культури УРСР, Державний комітет Ради Міністрів УРСР у справах будівництва та Головне архівне управління при Раді Міністрів УРСР [9, с. 10].

Відповідно до статті 1 Закону УРСР «Про охорону і використання пам'яток історії та культури», пам'ятками історії та культури визнавалися споруди, пам'ятні місця і предмети, зв'язані з історичними подіями в житті народу, розвитком суспільства і держави, твори матеріальної і духовної творчості, які становлять історичну, наукову, художню чи іншу культурну цінність [8].

Стаття 6 Цього Закону УРСР «Види пам'яток історії та культури» надавала розширене розуміння, які саме об’єкти історичної та культурної спадщини належали до пам'яток історії та культури. Це були:

- пам'ятки історії - будинки, споруди, пам'ятні місця і предмети, зв'язані з найважливішими історичними подіями в житті народу, розвитком суспільства і держави, революційним рухом, з Великою Жовтневою соціалістичною революцією, громадянською і Великою Вітчизняною війнами, соціалістичним і комуністичним будівництвом, зміцненням міжнародної солідарності, а також з розвитком науки й техніки, культури і побуту народів, з життям видатних політичних, державних, військових діячів, народних героїв, діячів науки, літератури і мистецтва;

- пам'ятки археології - городища, кургани, залишки стародавніх поселень, укріплень, виробництв, каналів, шляхів, стародавні місця поховань, кам'яні скульптури, наскельні зображення, старовинні предмети, ділянки історичного культурного шару стародавніх населених пунктів; 
- пам'ятки містобудування і архітектури - архітектурні ансамблі й комплекси, історичні центри, квартали, площі, вулиці, залишки стародавнього планування і забудови міст та інших населених пунктів; споруди цивільної, промислової, військової, культової архітектури, народного зодчества, а також зв'язані з ними твори монументального, образотворчого, декоративно-прикладного, садово-паркового мистецтва, природні ландшафти;

-пам'ятки мистецтва - твори монументального, образотворчого, декоративно-прикладного та інших видів мистецтва;

- документальні пам'ятки - акти органів державної влади й управління, інші письмові та графічні документи, кінофотодокументи і звукозаписи, а також стародавні та інші рукописи й архіви, записи фольклору і музики, рідкісні друковані видання.

До пам'яток історії та культури також могли бути віднесені й інші об'єкти, що становили історичну, наукову, художню чи іншу культурну цінність. Усі пам'ятки історії та культури, які знаходилися на території Української РСР, охоронялися державою [8]. Пам'ятник культури або природний об'єкт вважався взятим під охорону держави за умови, що відповідним органом прийнято про це спеціальне рішення, про яке повідомлено громадяни [7, с. 544].

Треба зазначити, що Закон УРСР 1978 року «Про охорону і використання пам'яток історії та культури» увібрав у себе попередні нормативні напрацювання та дещо віддзеркалював тодішній стан наукової методики охорони та реставрації пам'яток культури. Однак застійні явища в радянському суспільстві 1980-х років, глибока економічна криза спричинили невиконання цього Закону державними установами на всіх рівнях. Проте він залишався чинним понад два десятиліття [9, с. 10].

За своїми об'єктивними властивостями знищення пам'яток культури та природних об’єктів, узятих під охорону держави, полягало в їх повній ліквідації (наприклад, спалюється цінна картина, винищуються рідкісні тварини або птиці в заповіднику тощо). Під руйнуванням розумілося приведення пам'ятників культури або природних об'єктів у непридатність, чим знецінювалося їхнє наукове, історичне, художнє чи народногосподарське значення (наприклад, розбивається скульптура, розвалюється унікальна споруда, руйнується рослинний покрив). Псуванням вважалося таке пошкодження пам'яток культури або природних об'єктів, яке знижувало їхню наукову, історичну, художню цінність, народногосподарське чи культурно-естетичне значення (наприклад, забруднення картини, обламування деталей скульптури, заорювання ділянки землі в зоні заповідника) [7, с. 544].

Зазначене в статті 207 KК УРСР 1960 року діяння представляло собою спеціальний вид умисного знищення або пошкодження державного чи громадського майна, передбаченого статтею 89 KК УРСР 1960 року.

Із суб'єктивної сторони складу даного злочину припускалася виключно умисна форма вини. Винний усвідомлював, що своїми діями він знищує, руйнує або піддає псуванню пам'ятник культури або природний об'єкт, взятий під охорону держави, при цьому бажав настання цих наслідків або свідомо їх допускав. Мотивами злочину слугували різні спонукання: користь чи інша особиста зацікавленість, пустощі тощо.

Необережне знищення, руйнування чи псування пам'яток культури або природних об'єктів не тягло відповідальності за статтею 207 KK УРСР 1960 року, але за наявності необхідних до того ознак могло кваліфікуватися за статтею 90 КК УРСР 1960 року.

Суб'єктом розглядуваного злочину могла бути будь-яка особа, яка досягла шістнадцятирічного віку. 
Якщо злочин вчинявся посадовою особою, то за відповідних умов відповідальність наступала за сукупністю злочинів [7, с. 544-545]. У подальшому 3 метою вдосконалення кримінального законодавства Президія Верховної Ради Української РСР своїм Указом від 12 січня 1983 року внесла до КК УРСР зміни в заголовок і текст статті 207 KK УРСР, доповнивши норму після слова «пам'яток» словами «історії i» [10], поширивши таким чином коло предметів, на яке могло бути здійснено злочине посягання.

В Україні після набуття незалежності розпочався новий етап розвитку законодавства щодо охорони історичної та культурної спадщини. 5 квітня 2001 року Верховною Радою України був прийнятий перший Кримінальний кодекс незалежної України, в якому в розділі XII «Злочини проти громадського порядку та моральності» була представлена стаття 298 «Ниення, руйнування чи псування пам'яток історії або культури» [11], в подальшому стаття 298 KК України зазнавала неодноразових змін, адже вітчизняний законодавець постійно вдосконалював пам'яткоохоронне законодавство.

Висновки. Перший Кримінальний кодекс УСРР 1922 року характеризувався слабкою правовою охороною культурних цінностей. Існуючі законодавчі акти носили класовий характер і метою своєю мали вирішення політичних питань. Крім того, пробілом кримінального законодавства УРСР була відсутність закріплення інших видів посягань на культурні цінності, а саме: розкрадання, знищення або пошкодження тощо. У наступному KK УРСР 1927 року містилася лише одна норма, що охороняла пам'ятники історії і культури від злочинних посягань. Встановлювалася відповідальність за приховування колекцій і пам'ятників старовини і мистецтва, що підлягають реєстрації, обліку або передачі в державні сховища. У п'ятдесятих-шістдесятих роках минулого століття зміна суспіль- но-політичної обстановки, зосередженість суспільства на відновленні економіки держави та певна гуманізація призвели до значного зменшення злочинності проти історичної та культурної спадщини, що зумовило зниження уваги до проблем кримінально-правової охорони культурних та історичних цінностей. Так, у КК УРСР 1960 року відбулася декриміналізація діяння, яке полягало в приховуванні колекцій i пам'ятників старовини і мистецтва, що підлягають реєстраціі, обліку або передачі в державні сховища, і була запроваджена принципово нова норма про знищення i зруйнування пам'яток культури, передбачена ст. 207 KK УРСР 1960 року. Перший Кримінальний кодекс незалежної України передбачив статтю 298 «Нищення, руйнування чи псування пам'яток історії або культури». У подальшому ця норма зазнавала неодноразових змін, адже вітчизняний законодавець постійно вдосконалює пам'яткоохоронне законодавство.

Статтю присвячено дослідженню історії розвитку вітчизняного законодавства про охорону об’єктів історичної та культурної спадщини. Визначено основні етапи еволюuіï u̧ього інституmy у XX cmorimmi, зокрема щзодо його кримінально-правового захисту. Отже, перший Кримінальний кодекс УРСР 1922 року характеризувався слабкою правовою охороною культурних циінностей. Існуючі законодавчі акти носили класовий характер $і$ метою своєю мали вирішення політичних питань. Крім того, пробілом кримінального законодавства УРСР була відсутність закріплення інших видів посягань на культурні цінності, а саме: розкрадання, знищення або пошкодження тощо. У наступному КК УРСР 1927 року містилася лише одна норма, що охороняла пам'ятники історії $i$ культури від злочинних посягань. Встановлювалася відповідальність за приховування колекцій $i$

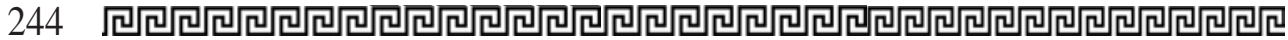


пам’ятників старовини і мистеитва, що підлягають реєстраціі, обліку або передачі в державні сховища. У n'ятдесятих-шістдесятих роках минулого століття зміна суспільно-політичної обстановки, зосередженість суспільства на відновленні економіки держави та певна гуманізачія призвели до значного зменшення злочинності проти історичної та культурної спадщини, що зумовило зниження уваги до проблем кримінально-правової охорони культурних ma історичних цінностей. Так, у KK УРСР 1960 року відбулася декриміналізація діяння, яке полягало в приховуванні колекцій $i$ пам'ятників старовини і мистеитва, що підлягають реєстрації, обліку або передачі в державні сховища, $і$ була запроваджена принципово нова норма про знищення $i$ зруйнування пам'яток культури, передбачена ст. 207 KK УРСР 1960 року. Перший Кримінальний кодекс незаленної України передбачив статтю 298 "Нищення, руйнування чи псування пам'яток історії або культури». У подальшому ия норма зазнавала неодноразових змін, адже вітчизняний законодавецъь постійно вдосконалюе пам'яткоохоронне законодавство.

Ключові слова: кримінальне право, об'єкти історичної та культурної спадщини, кримінально-правовий захист.

Gulyakov K. Evolution of legislation on protection of objects of historical and cultural heritage during the XX century

The article is devoted to the study of the history of the development of domestic legislation on the protection of objects of historical and cultural heritage. The main stages of the evolution of this institution in the twentieth century, in particular, its criminal-legal protection, have been determined. So, the first Criminal Code of the Ukrainian SSR in 1922 was characterized by weak legal protection of cultural values. The existing legislative acts were of a class nature and aimed at solving political issues. In addition, a gap in the criminal legislation of the Ukrainian SSR was the lack of consolidation of other types of encroachments on cultural values, namely: theft, destruction or damage, etc. In the next Criminal Code of the Ukrainian SSR in 1927, there was only one norm that protected historical and cultural monuments from criminal encroachments. Responsibility was established for the concealment of collections and monuments of antiquity and art, subject to registration, accounting or transfer to state depositories. In the fifties and sixties of the last century, the change in the socio-political situation, the concentration of society on the restoration of the state economy and a certain humanization led to a significant decrease in crime against historical and cultural heritage, caused a decrease in attention to the problems of criminal protection of cultural and historical values. Thus, in the 1960 Criminal Code of the Ukrainian SSR, the decriminalization of the act took place, which consisted in the concealment of collections and monuments of antiquity and art subject to registration, accounting or transfer to state depositories, and a fundamentally new norm on the destruction of cultural monuments was introduced, provided for by Article 207 of the Criminal Code USSR 1960. The First Criminal Code of Independent Ukraine provided for Article 298 "Destruction or damage of monuments of history or culture". In the future, this norm has experienced repeated changes, because the domestic legislator is constantly improving the protective legislation.

Key words: criminal law, objects of historical and cultural heritage, criminal law protection. 


\section{Література}

1. Уголовный кодекс УССР, утвержденный ВУЦИК 23 августа 1922 г. (с измен. и дополнениями по 1-ое июня 1924 года и с алфав. указателем). 6-е офии. издание. Харьков : Юридическое Издательство Наркомюста УССР, 1924. $104 \mathrm{c}$.

2. Одайник Б.М. Кримінальна відповідальність за знищення, руйнування або пошкодження пам'яток - об'єктів культурної спадщини : дис. ... канд. юрид. наук : 12.00 .08 ; Одес. наи. ун-т ім. I.I. Мечникова. Одеса, 2010. 215 с.

3. Кримінальний кодекс УСРР: у редакиіï 1927 року. 3-те офіи. вид. Харків : Юридичне Видавництво Наркомюсту УРСР, 1927. 109 с.

4. Кудерська Н.I. Становлення $i$ розвиток законодавства про охорону культурної спадщини в Україні. Університетські наукові записки. 2011. № 3. С. 20-26.

5. Kот C.I. Охорона пам'яток істоpiï та культури. Енщиклопедія історіі України : у $10 \mathrm{~m}$. ; редкол. : В.А. Смолій (голова) та ін. Київ : В-во «Наукова думка», 2010. T. 7: Мi-O. 728 с.

6. Кримінальний кодекс Української РСР / редактори-упорядники В.В. Меленевський, С.С. Яиенко. Київ : Державне видавництво політичної літератури УРСР, 1961. $210 \mathrm{C}$.

7. Уголовный кодекс Украинской ССР. Научно-практический комментарий / Н.Ф. Антонов и др. ; отв. ред. В.И. Зайчук, С.С. Яиенко. Киев : Политиздат Украинь, 1978. 684 с.

8. Про охорону і використання пам'яток історії та культури : Закон Української Радянської Соціалістичної Республіки від 13 липня 1978 р. № 3600-IX. URL: https: / / zakon.rada.gov.ua/laws / show / 3600-09 (дата звернення: 20.05.2020).

9. Пам'яткознавство: правова охорона культурних надбань: зб. док. / упоряд. Л.В. Прибєга. Київ : Iн-т культурологї̈ Акад. мистеи. України, 2009. 416 с.

10. Про внесення змін $i$ доповнень до Кримінального кодексу Української РСР : Указ Президіі Верховної Ради Української Радянської Соціалістичної Республіки від 12 січня 1983 р. № 4571X. URL: https://zakon.rada.gov.ua/ laws/show/4571-10 (дата звернення: 20. 05. 2020).

11. Кримінальний кодекс України Закон України від 05 квітн. 2001 р. № 2341 III. URL: https: / / zakon.rada.gov.ua/ laws/show/2341-14/ed20010405 (Jama звернення: 10. 06. 2020). 